\section{Snješka Knežević}

samostalna istraživačica independent researcher

Visoka 20

Zagreb, Hrvatska

snjeska.knezevic@zg.t-com.hr

iD orcid.org/0000-0002-3880-3621

Izvorni znanstveni rad

Original scientific paper

UDK / UDC:

711.4(497.5 Zagreb)"18”

DOI:

10.17685/Peristil.62.2

Primljeno / Received:

15. 9. 2019.

Prihvaćeno / Accepted:

20. 12. 2019.

\section{Urbanističke osnove Zagreba u razdoblju modernizacije}

\author{
Urban Planning of Zagreb \\ in the Age of Modernization
}

\begin{abstract}
APSTRAKT
Detaljno se predstavljaju dvije generalne regulatorne osnove nastale u doba modernizacije, 1865. i 1887. godine. Prvom je prostorno i sadržajno definiran Donji grad, koji će postati nositeljem urbanističko-arhitektonskog i kulturnog identiteta Zagreba te do danas ostati njegovim središtem. Drugom se osnovom predviđalo znatno proširenje grada sa zapada, napose s istoka, a novost je uvođenje zoninga. Tako prvi razdjel (zona) obuhvaća Donji grad s ekstenzijama i nositelj je centraliteta, drugi je namijenjen industrijskoj zoni, a treći rezidencijalnom predjelu s obilježjima vrtnoga grada. Na kraju se iznosi radikalno rješenje krucijalnog problema, tzv. željezničkog čvora kao hipoteke i nasljeđa obiju osnova. Predložio ga je Milan Lenuci 1907., nadomak moderne. Tim bi rješenjem bio omogućen homogen i harmoničan razvoj Zagreba kao metropole - da je bilo prihvaćeno.
\end{abstract}

\section{KLJUČNE RIJEČI}

urbanizam, Zagreb, regulatorna osnova, Milan Lenuci, modernizacija, 19. stoljeće

\section{ABSTRACT}

The paper gives a detailed analysis of two general regulatory plans drafted in the age of modernization, in 1865 and 1887 respectively. The first provided a spatial and functional definition of the lower part of the city (Donji grad), which would later become the key element of Zagreb's urban, architectural and cultural identity and remain the city's centre to this day. The second regulatory plan envisaged a significant expansion of the city from the west and especially from the east, and the novelty was the introduction of zoning. The first zone comprised the Lower Town with extensions and represented the very centre, the second was intended for industry and the third as residential area with features of a garden city. The radical solution to the crucial problem of the so-called rail node as a pledge and legacy of both plans was proposed by Milan Lenuci in 1907, on the eve of modernism. This solution would have enabled the homogeneous and harmonious development of Zagreb as a metropolis - had it been accepted.

\section{KEYWORDS}

urban planning, Zagreb, regulatory plan, Milan Lenuci, modernization, 19th century 


\section{Uvodna napomena}

U razdoblju modernizacije, ${ }^{1}$ formativnom za urbanističku fizionomiju Zagreba, donesene su dvije urbanističke (regulatorne) osnove, 1865. i 1887. godine, a gotovo na isteku epohe, 1907. godine, Milan Lenuci podnio je skicu nove osnove. Prva i druga osnova bitno su odredile urbanistički razvoj grada te bile predmetom istraživanja povjesničara umjetnosti, pionira na polju gradogradnje od 1960-ih nadalje. ${ }^{2}$ Lenucijeva skica ostala je zagubljena, otkrivena je tek 1990-ih i potom prezentirana. ${ }^{3} \mathrm{Za}$ razliku od prve i druge regulatorne osnove nije imala izgleda za realizaciju - ne zato što kao skica, kako ju je nazvao sam autor, ne bi imala težinu legitimnog dokumenta, nego zbog radikalnosti koja nije bila prihvatljiva u tadašnjim okolnostima. Sve tri osnove, bez obzira na format i opremu, imaju karakter generalnih i razvojnih osnova, zato što se bave cijelim gradskim teritorijem, predviđaju njegovo znatno proširenje i imaju dugoročni karakter. No naziv „generalni plan” pojavljuje se tek na prijelomu 19. u 20. stoljeće: Generalplan (Fassbender, 1912.), Generalregulierungsplan (Gurlitt, 1920., Hoepfner, 1921./1928., Schumacher, 1951.). ${ }^{4}$ Tako se prva osnova iz 1865. naziva „osnova za razprostranjenje i poliepšanje grada", kako se u to doba u Austrijskom Carstvu naziva većina osnova sličnog karaktera; druga iz 1887. samo je „regulatorna osnova”, dok Lenuci svoju „škicu” iz 1907. naziva „generalna osnova o budućem razvitku grada Zagreba".

Prvoj osnovi opširne studije posvećuju Eugen Franković (Franković, 1981.) i Olga Maruševski (Maruševski, 1983.), ocjenjujući je različito. Franković je smatra najvažnijim dokumentom epohe, Maruševski mjerničkom (crtačkom), bez umjetničkih oblikovnih pretenzija. Lelja Dobronić, koja je prva obratila pozornost na arhitekturu i urbanistički razvoj Zagreba u 19. stoljeću, predstavlja osnove iz 1865. i 1887. u dva pregleda (Dobronić, 1961., Dobronić, 1962.) ekstenzivnim navodima iz tekstova osnova, ne i planovima. Drugom osnovom bave se u većim studijama Franković i Maruševski. Franković (1978.) je smatra izvedenicom osnove iz 1865., manje inovativnom i ,oktroiranom" politički; interes mu je usmjeren na hipotetički udio Hermana Bolléa. Maruševski 1986. upućuje na Lenucijevu formulaciju kako je ta osnova prilagođena „novim umjetnim odnošajima”, donosi komparaciju sa srednjoeuropskim primjerima i uzorima te razmatra udio Izidora Kršnjavoga u planiranju. I jedna i druga (generalna) osnova u navedenim studijama prikazane su „monografski”, s težištem na valorizaciji intencija, ali i njihove realizacije.

Cilj ovog rada je prikazati permanentnu transformaciju, točnije: evoluciju od prve osnove (1865.) do druge (1887.) i napokon do Lenucijeva prijedloga iz 1907. godine. Riječ će biti o procesima i okolnostima koji su izazivali potrebu revizije urbanističkih koncepata osnova netom što su formulirane ili o složenosti motivacija, koja se nipošto ne može svesti na političko, čemu je sklon Franković, ni na puki pragmatizam protagonista ili institucija, odgovornih za prostorno planiranje. Prikaz se zasniva ponajprije na vlastitim istraživanjima urbanističkog planiranja i razvoja od kraja 1980-ih do danas te kritičkom čitanju izvora i literature, pozivom na misao Milana Preloga da je svaka znanost (istraživanje) uvijek na početku.

\section{Naznake planiranja u doba protomodernizacije}

Iako se modernizacija formalno utvrđuje ujedinjenjem gradskih jurisdikcija u jedinstven organizam 1850. u sklopu velikih reformi Franje Josipa I., ona zahvaća Zagreb znatno kasnije nego druge krunovine Austrijskog Carstva. ${ }^{.}$Štoviše, ,„šok ujedinjenja” otežavao je usklađivanje interesa biskupskog i slobodnog kraljevskoga grada, donošenje jedinstvenih planova ekonomskog i prostornog razvoja. Prema Mirjani Gross, antagonizme se nije uspjelo prevladati u doba neoapsolutizma. ${ }^{6} \mathrm{Uz}$ to, modernizaciju su kočili siromaštvo, političke krize i represija te, čini se, i nedovoljno snažna urbana svijest. Tek padom neoapsolutizma (1859.) pojavljuju se pretpostavke za modernizaciju koja će započeti 1860-ih godina (u tzv. neoilirsko doba) i doći do zamaha u doba banovanja Ivana Mažuranića (1873.-1880.) kada se donose važne reforme za sva područja života.

Veći dio dotadašnjih inicijativa usmjeren je „poljepšanju” grada, uglavnom redotvornim intervencijama, ne i planiranju kao razvojnom načelu. O prostornom proširenju grada, ne još o nekom planu, riječ je tek u dokumentu iz 1857. godine, koji sadrži prvi cjeloviti popis gradskih potreba. No plansku urbanizaciju budućeg novoga predjela, Donjega grada, najavljuje „Red gradjenja za zemaljski glavni grad Zagreb”, koji je 1. veljače 1857. objavilo C. kr. Hervatsko-slavonsko miestoderživo, dakle, vlada. Iako se taj dokument ne bavi razvojnim perspektivama, nego prije svega donosi gradevne norme, higijenske standarde i propise, u njemu se navodi: „Da se gradu malo 
po malo pribavi pravilnije obličje, osnovat će se na temelju napervo učinjenoga narisa i niveliranja plan za reguliranje grada." 7 No do njegove izrade proteći će osam godina.

Početkom 1860-ih nastaju najprije prostorne osi novog Donjega grada povezivanjem prometnih i privrednih objekata s glavnim čvorištima i arterijama urbanog života. Za prostorni koncept Donjega grada od presudne je važnosti bila urbana trasa željezničke pruge Zidani Most - Sisak i lokacija kolodvora Južne željeznice. ${ }^{8}$ Utvrdena je 2. srpnja 1860 . komisijskim obilaskom terena zbog izgradnje pruge. Tema prijepora i rasprava bila je lokacija kolodvora na zapadnom kraju grada i njegovo povezivanje s gradom. ${ }^{9}$

Predstavnici Grada utvrđuju da „nije u savezu sa ni jednom deržavnom cestom" i traže od države sufinanciranje gradnje ceste koja bi ublažila nedostatke lokacije. U zahtjevu za njezino sufinanciranje izložen je prostorni skelet zapadnog dijela grada između Savske ceste i novog kolodvora. Osim o prioritetnoj cesti kojom bi kolodvor bio povezan s Novim tergom (od 1866. Trgom Nikole Šubića Zrinskoga), riječ je i o drugoj cesti sličnoga značaja i važnosti koja bi sezala od južne strane Novog terga do Južnoga kolodvora (danas Zapadnoga) i povezala ga s Donjim gradom (današnje Hebrangova i Klaićeva ulica). Između tih dviju prometnih arterija zamišljen je „,vele liepi novi terg”, za čije je oblikovanje vrlo važna monumentalna zemaljska zgrada namijenjena bolnici, sagrađena 1859. (danas sjedište Rektorata Sveučilišta i Pravnog fakulteta). Građevna linija te zgrade glavno je uporište predložene regulacije. Zahtijeva se da ulica teče usporedo sa zgradom, što upućuje na težnju valorizaciji njezina pročelja kao reprezentativnog začelja trga. Spis u kojemu se od zemaljskih vlasti traži sufinanciranje gradnje nove ceste važan je urbanistički dokument Zagreba.

U njemu se prvi put jasno iznose elementi regulacije zapadnog dijela Donjega grada. Osobito je važan za genezu parkovnog okvira središta, Lenucijeve ili Zelene potkove, zato što utvrđuje njezino zapadno ishodište: drugi donjogradski trg (danas Trg Republike Hrvatske). Samo središte Donjega grada prvi je put definirano u vladinu dokumentu iz 1862.: „,medj Jelačićevim tergom i Savskom ulicom”.

Od 1861. Hrvatska dvorska kancelarija iz Beča i Namjesničko vijeće iz Zagreba zahtijevaju izradu plana prostornog razvoja grada. Iako je o tome 11. lipnja 1863. donesena odluka, izrada se oteže i obrazlaže nedostatkom adekvatnog plana grada. Taj plan, ubrzo dovršen i prezentiran gradskoj skupštini 19. travnja 1864., prikazuje situaciju prije ili tijekom izrade regulatorne osnove. ${ }^{10}$ Najuočljivija je promjena pravilnost parcelacije na onom prostoru koji je 1862. obilježen kao središte Donjega grada. Nekadašnja nepravilna ruralna struktura pretvorila se u pravilnu razdiobu $u$ jednolične izdužene pravokutne gradske parcele duž izgrađenih poteza, što svjedoči o počecima urbanizacije tog područja.

Jedan od poticaja za dovršenje prve regulatorne (generalne) osnove zacijelo je bila Prva dalmatinsko-hrvatska-slavonska gospodarsko-šumarska izložba održana 1864. godine. Težište je bilo na uređenju Novog terga: s Jelačićeva trga na njega bi se premjestilo tržište, a iz Novog terga izmjestilo bi se stočno sajmište. Odluka o premještanju tržnice i stočnog sajmišta 1864. godine dopušta pretpostavku da je regulatorna osnova u to doba, dakle godinu dana prije prezentacije, već bila uglavnom postavljena.

\section{Regulatorna osnova iz 1865.}

Osnova za razprostranjenje i poliepšanje grada Zagreba predstavljena je i odobrena tijekom 1865. godine. ${ }^{11}$ Izrada je bila povjerena užem, tehničkom odboru, sastavljenom od trojice iskusnih i poznatih inženjera, Vatroslava Egersdorfera, Janka Nikole Grahora i Kamila Bedekovića te dvojice senatora, Adolfa Hudovskog i gradskog kapetana Nikole Urice. Predsjednikom je od početka (1863.) bio vitez inženjer Josip (Josef Alexander) Bouffleur, ravnatelj Zemaljske građevne direkcije za Hrvatsku i Slavoniju, no pošto je bio umirovljen i otišao iz Zagreba, 1864. Egersdorfer je „preuzeo izradjenje osnove”, kako je to na početku prezentacije objasnio gradski načelnik Vjekoslav Frigan. Egersdorfer se s dosta pouzdanja, pa i s pravom, može smatrati autorom osnove. ${ }^{12}$ Rad na osnovi pratio je poslije Bouffleura kao savjetnik barun inženjer Leonard Zornberg, nadinspektor Zemaljske građevne direkcije. ${ }^{13} \mathrm{U}$ širem odboru bilo je osim stručnjaka nekoliko gradskih zastupnika, a po dužnosti dvojica senatora, od kojih je Adolf Hudovski bio osobito aktivan. ${ }^{14}$

Regulatorna (generalna) osnova Zagreba sastoji se od tri tekstualna dokumenta: Obrazloženje potriebe i načina, kako da se uredi slobodni i kralj. glavni grad Zagreb, i kako da se ovo uredjenje uz postupno razprostranjivanje grada sredstvom statuta olakhoti i osiegura, Zapisnik siednicah od 13., 
17., 18, 21. i 23. siečnja 1865. dèržanih po odboru ad hoc, izabranog po gradskomu zastupstvu glede izradjenja osnove za razprostranjenje i poliepšanje grada Zagreba i Izvadak iz Zapisnika sjednice zastupstva sl. i kr. glavnog grada Zagreba držane dne 23. ožujka 1865. te drugog izdanja Albrechtova Nacrta Zagreba, kojem je dodan drugi list s prikazom područja od željezničke pruge do rijeke Save i na njima ucrtana regulacija ${ }^{15}$ (sl. 1).

U Obrazloženju se navode dva „razdiela” (dijela) osnove: tergovačko-politički i tehnički. Prvi je elaborat u kojem se iznose glavni elementi na kojima se zasniva prijedlog osnove: geopolitičke odrednice, topografska obilježja, prometna problematika (ceste, željeznice, plovni putovi), očekivanja i perspektive trgovačkog, privrednog i ekonomskog rasta. Izlažu se i političke okolnosti koje određuju prilike u Kraljevini Hrvatskoj i Slavoniji, europski kontekst i u njemu položaj Habsburške Monarhije. Indirektno tekst sadrži kritiku austrijskog političkog sustava, administrativne organizacije i feudalnog mentaliteta, znatnog kašnjenja za Europom i sustajanja u donošenju reformi: ukratko, pledira se za moderni kapitalizam i liberalizam. Elaborat je imao dvojaku funkciju: obrazložiti, ali i osnažiti viziju prostornog razvoja grada. Taj teorijski prilog legitimira osnovu kao jedinstven dokument modernizacije. Iza nje stoji elita tehničke inteligencije.

U tehničkom se dijelu prema redu važnosti detaljno navode elementi koji bi imali osigurati provedbu osnove: intervencije u „starome” gradu (Gornjem gradu i Kaptolu), uređenje „novoga prediela” (Donjega grada) i povezivanje tih urbanih područja; nadalje, popis novih ulica i trgova te postojećih koje treba regulirati; popis javnih (upravnih, sudbenih, obrazovnih, kulturnih) sadržaja u oba dijela grada - na Gornjem gradu onih koji bi ondje ostali, u Donjemu gradu mahom novih. Za Donji grad predlaže se model urbanizacije „naherpe kućah”, tj. blokovska izgradnja i ortogonalni ulični sustav, a određuju mu se i dimenzije (,ne smije se graditi kuće više nego li na tri kata”), dok bi ulice s obzirom „na predvidno obćenje i na savez sa obstojećim ulicama" imale širinu od 5,8 do 12 hvati, ${ }^{16}$ nove u pravilu šireg profila.

Što se tiče prometa, predlažu se dvije verzije urbane trase budimpeštanske pruge (najavljene dionice Nagykanizsa - Zagreb), njezino spajanje s postojećom prugom Zagreb - Sisak i zajednički most preko Save. Južno od pruge (na području Trnja) predviđeni su novi „osrednji” (središnji) kolodvor, iza njega luka, s njome povezan plovni kanal od Rugvice i Save ${ }^{17}$ i produljenje Petrinjske ulice duž paromlina (otvoren 1862.) sve do Save (kasnija Trnjanska ulica). Sa zapadne strane Savske ceste, pokraj vojnog opskrbnog magazina (na mjestu sadašnjeg hotela Westin) gradila bi se golema vojarna, a nešto južnije predviđena je prostrana površina za radničko naselje (zaselak, ville). Dalje prema zapadu, pokraj Južnoga kolodvora, predviđa se prostrano stočno sajmište („novi marvinski terg”). Novi trg predviđa se i sjeverno od kolodvora, a kolodvor i trg povezali bi se s Ilicom novom ulicom (danas Republike Austrije). Sadržaji - željezničko-lučki kompleks, radničko naselje, stočno sajmište i kolodvor - predodređuju područje južno od pruge i oko postojećeg Južnog kolodvora kao industrijsku zonu.

Moderne higijenske standarde zadovoljilo bi se premještanjem potoka Medveščaka iz grada, gradnjom vodovoda i kanalizacije, uređenjem novoga groblja (na mjestu uboškoga, „bogečkoga”, na Vinogradskoj cesti), odnosno ukidanjem starih groblja i grobnica u crkvama ili pokraj njih. Napokon, kao mjera za realizaciju regulacije i proširenja grada predlaže se sustavna nabava zemljišta, a kao alat novi statut kojim bi se dopunio postojeći Gradevni red (iz 1857.). Potonji se očito smatra nedovoljno razrađenim, možda i zastarjelim za realizaciju svega što se predvida. Zagrebu se, u doba kad ima nešto više od 16 ooo stanovnika (1850. - 16 036, 1869. - 19857$)$, predvida rast do "40-50 hiljadah" i prostorni razvoj do željezničkih pruga, ali se ne isključuje ni mogućnost proširenja preko njih, prema jugu, bude li to „u svakako još dalekoj budućnosti triebalo".

Prva regulatorna osnova iz 1865. godine nadasve je važna zato što prostorno i sadržajno definira Donji grad, njegovu integrativnu funkciju - spajanje povijesnih naselja s podgradima, ujednačavanje urbanog standarda i urbanističku konsolidaciju. Bila je podloga nastanka Donjega grada, nositelja urbanističko-arhitektonskog i kulturnog identiteta Zagreba. Naglašava se „velik zadatak koji ima obćina grada Zagreba u obziru raszprostranjenja i poljepšanja grada", ali i uvjerenje u njegove mogućnosti, riječju: optimizam. Tako se od unapređenja željezničkog prometa očekuje da će Hrvatska „do skora uvèršćena biti u evropejsku željezničku mrežu, pa da će joj glavni grad naš Zagreb u ovoj mreži čvor i sveza biti”.

Granice Donjeg grada definirane su sa sjevera Ilicom i Vlaškom ulicom, s juga očekivanom 


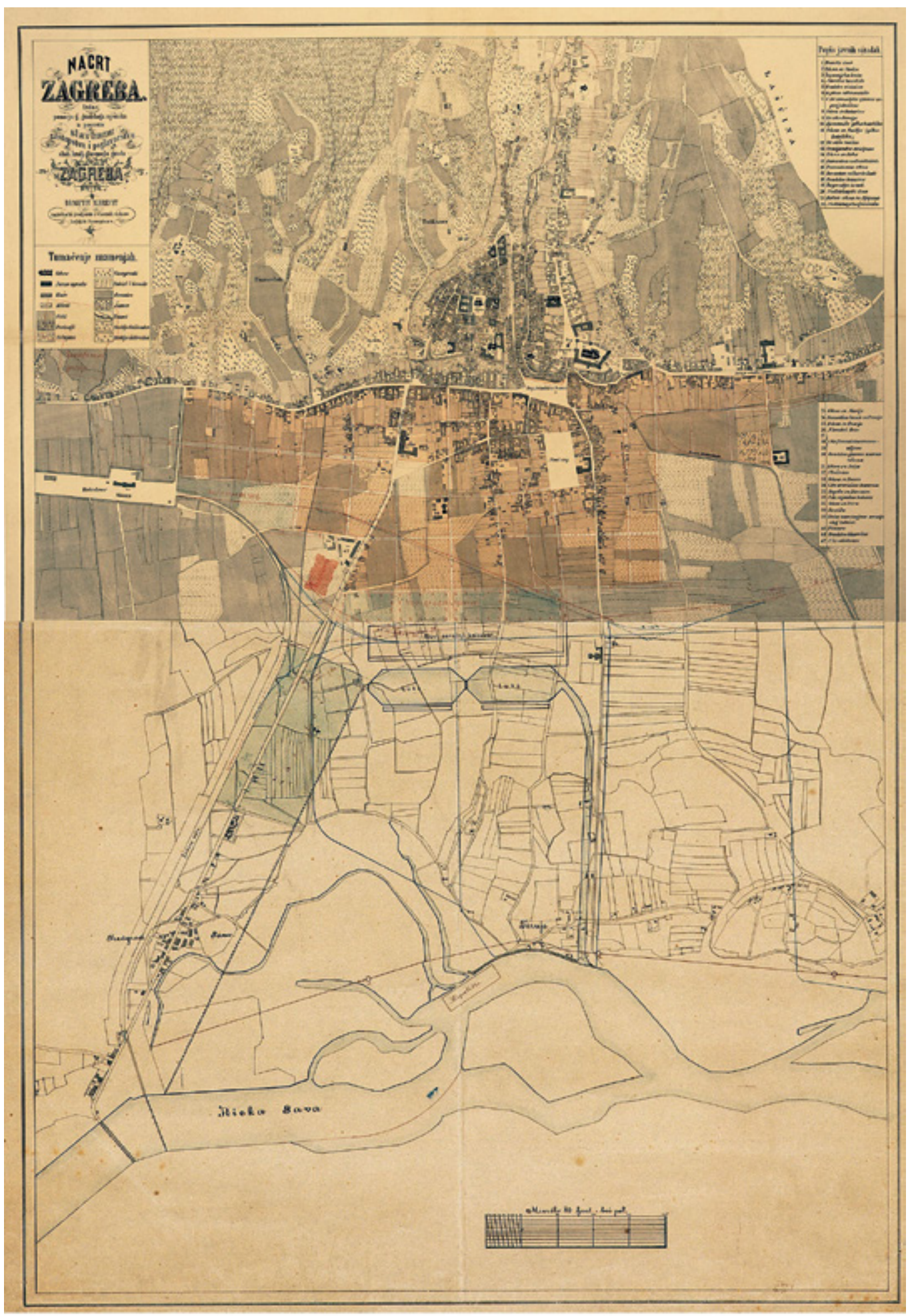

1 Prva regulatorna osnova Zagreba, 1865

Muzej grada Zagreba, Zbirka planova, br. 1878 (gornji list)

Nacionalna i sveučilišna knjižnica Zagreb, Zbirka zemljovida $\mathrm{i}$ atlasa, $\mathrm{X}-\mathrm{H}-\mathrm{J}-24$ (donji list)

The first regulatory plan of Zagreb, 1865

Zagreb City Museum, Plans Collection, n. 1878 (upper sheet)

National and University Library in Zagreb, Map Collection,

$\mathrm{X}-\mathrm{H}-\mathrm{J}-24$ (lower sheet) 
budimpeštanskom prugom, sa zapada Južnim kolodvorom (poslije Zapadnim) i s istoka današnjom Draškovićevom ulicom s ekstenzijom do nove gradske klaonice (u današnjoj Bauerovoj ulici). Središte Donjega grada („nutarnji grad” ili Innenstadt) opisano je kao „prediel grada napram Gornjemu gradu sa medjami Savske i petrinjske ulice". Označeno je dvama trgovima i parkom: s istoka Novim tergom (Trgom Nikole Šubića Zrinskoga), sa zapada bezimenim trgom južno od zemaljske zgrade namijenjene bolnici, s juga „novim gradskim perivojem". Novi terg je formativna jedinica plana. Njegove dimenzije postuliraju novo, znatno veće mjerilo i gradu i budućoj arhitekturi. Bezimenom trgu, na zapadnom rubu središta, nastoji se osigurati pravilan oblik. Trgove sa sjeverne strane spaja povijesna komunikacija (Nikolićeva/Teslina - Marovska/Masarykova), s južne strane nova prometnica u produženju južne obodnice Novoga terga. Novi gradski park smješten je duž trase očekivane željezničke pruge Budimpešta - Zagreb. Lokacija novog kolodvora te pruge utvrđena je u sredini, između meda „nutarnjega grada”, Petrinjske ulice i Savske ceste, u osi buduće ulice X (Gundulićeve). Prostran, izduženi park razdvaja središnje, rezidencijalno područje od tehničko-industrijske sredine južno od pruge u Trnju. Perivojem se uvodi moderan sadržaj, potvrđen u bliskim središtima: u Beču starijim Volksgartenom i suvremenim Stadtparkom, a u Budimpešti Varosligetom.

U Donji grad osnova smješta deset novih javnih sadržaja: novu gradsku vijećnicu na Jelačićevu trgu; jednu župnu crkvu na Novom tergu, drugu na novoj cesti (Prilazu Gjure Deželića); natkrivenu tržnicu u sredini Novoga terga; dječačku pučku školu na uglu Samostanske ulice (Varšavske) i nove ulice $\mathrm{X}$; zgradu županijskog suda sa zatvorom i izložbenu zgradu na trgu ispred bolnice (Trgu Republike Hrvatske), a u postojeću bolničku zgradu smješta opću bolnicu, ranarnicu, kliniku, rodilište, školu za primalje i nahodište; novo kazalište bilo bi u Ilici (na „Jelačićevom zemljištu”, u bloku Ilica - Bogovićeva - Petrićeva - Margaretska ulica), a sinagoga u novoj ulici prema Novom tergu (Praškoj ulici). Naknadno je predloženo da se na Novom tergu grade zgrada Glazbenog zavoda, dački dom za polaznike preparandije i radionica ženske kaznione; bolnica milosrdne braće premjestila bi se s Jelačićeva trga u franjevački samostan na Kaptolu. Neki će sadržaji biti ostvareni, a za druge o kojima će biti riječi idućih desetljeća uvijek će se računati na ta dva trga iz regulatorne osnove.
No sadržaji su na trgovima okupljeni nasumce. Postojeće i novo nije dovedeno u sklad. Tako se u središte Novog terga smješta tržnica, na istočnoj strani ostaju Petrinjska vojarna i ženska kaznionica s novom radioničkom zgradom; na zapadnoj strani, uz Oružničku vojarnu u privatnoj kući Hatz (na mjestu današnjeg Arheološkog muzeja), predlaže se nova župna crkva, a uz nju đački dom i zgrada Glazbenog zavoda. Na drugom, još neimenovanom trgu (danas Trgu Republike Hrvatske), u susjedstvu Plinare i gradskog majura, u novoj zemaljskoj zgradi predviđen je bolnički centar, na istočnoj strani zgrada županijskog suda, na zapadnoj izložbena (muzejska?) zgrada. Te opreke s pravom postavljaju pitanje arhitektonske fizionomije budućih trgova: historicizam, naime, za svaki sadržaj zahtijeva stilsku karakterizaciju, a moguća bi realizacija donijela zbrku. Trgovi napokon nisu ostvareni prema tim zamislima, ali je u Donjemu gradu s vremenom realizirana ulična mreža gradnjom novih ulica, preuređenjem i proširenjem (regulacijom) starih.

Gornjemu gradu osnova nije donijela nekih novosti zadržavši ondje većinu institucija, a samo je za novu zgradu Hrvatskog sabora predložena lokacija na mjestu bivšeg kapucinskog samostana i pavlinske kurije, adaptiranih u 19. stoljeću za stanove (današnji Park Bele IV.). Predloženi su i neki premještaji: gimnaziju bi se smjestilo u staru gradsku vijećnicu, možda i u kazalište kad bude otvoreno sveučilište, a njemu bi se namijenila gimnazijska zgrada na Katarinskom trgu - sve u perspektivi gradnje nove vijećnice i kazališta u Donjemu gradu kamo bi se preselili iz Gornjega grada. Svojevrsnim amandmanom barun Zornberg predložio je da se sruši župna crkva sv. Marka (osim tornja), a nova sagradi pokraj župnog dvora.

Kaptol se planira otvoriti središtu grada regulacijom Bakačeve ulice i Splavnice te „raščistiti” od starina koje se ne smatra vrijednima očuvanja: srušilo bi se staru baroknu kaptolsku vijećnicu i zapadni zid s Metropolitanskom knjižnicom i Bakačevim tornjem ispred katedrale te sjeverna kaptolska vrata. Na Opatovini, točnije u sklopu tzv. Plemićeve palače ostaju muška i djevojačka pučka škola.

\section{Prema reviziji regulatorne osnove iz 1865.}

Nove ideje i urgentni zahtjevi izazivat će razmatranja utvrdenih elemenata osnove, poticati ideje o njezinoj reviziji i najposlije dovesti do izrade nove regulatorne osnove. Presudnu ulogu u tom 
procesu imale su odluke o uokvirenju središta Donjega grada perivojnim trgovima (tzv. Lenucijeva ili Zelena potkova) i novoj lokaciji kompleksa vojarni na istočnom rubu grada.

Potkraj 1869. godine dolazi do vrijednosnog obrata prema Trgu Nikole Šubića Zrinskoga: umjesto tržišta na njemu bi se uredio perivoj. Estetskoj i socijalnoj funkciji daje se prednost pred utilitarnom. Sljedeće, 1870. godine, plan perivoja izradio je predstojnik Gradskog građevnog ureda Rupert Melkus. ${ }^{18}$ Stočno sajmište premjestilo bi se na još neimenovani trg ispred zgrade namijenjene zemaljskoj općoj bolnici, a Melkusu je naloženo da podnese prijedlog njegova preuređenja. Trg N. Š. Zrinskoga prvi je primjer prenamjene kojom je potpuno izmijenjen planirani karakter prostora. Uređivanje trga potrajalo je tri godine; perivoj je predan u uporabu u ljeto 1873. godine.

Razmatranja lokacije palače Jugoslavenske akademije znanosti i umjetnosti sa Strossmayerovom galerijom u Donjemu gradu (pošto se odustalo od lokacije u Parku Grič na Gornjemu gradu) dovodi do ideje produljenja Trga N. Š. Zrinskoga sličnim trgom. Presudnu ulogu imao je vladin savjetnik Mirko pl. Halper Sigetski ${ }^{19}$ prijedlogom lokacije na neurbaniziranom području južno od zrinjevačkog perivoja i novoga trga iz 1876. godine. Sljedeće, 1877. godine, u studiji posvećenoj smještaju jedanaest novih sadržaja u Donjemu gradu inženjer Juraj Augustin, predstojnik vladina Građevnog odsjeka, ${ }^{20}$ formira južno od Trga N. Š. Zrinskoga tri perivojna trga sve do željezničke pruge. Dio sadržaja smješta na obode Trga, a na nove trgove dvije palače Narodnog muzeja, sveučilišne institute, botanički vrt i park (,javna pohađališta”). Za razliku od trgova u važećoj regulatornoj osnovi, na kojima su sadržaji nagomilani bez obzira na njihovu namjenu, Augustin stvara tematske ansamble i njima definira karakter trgova. Kao interni vladin dokument studija nije mogla utjecati na gradske odluke, ali je imala odjeka. Na nju se po svoj prilici oslanja novinska bilješka u kojoj se neposredno prije katastrofalnog potresa 9. studenoga 1880. spominje „budući gradski perivoj, koji će se protezati do žakanjske željezne pruge”. Riječ je o trodijelnom prospektu koji će poslije biti nazvan Istočni perivoj (trgovi N. Š. Zrinskoga, J. J. Strossmayera i kralja Tomislava).

Poticaj za formiranje kontinuiranog zelenog okvira središta Donjega grada stiže 1882. od Sveučilišta koje je te godine iz Gornjega grada premješteno u zgradu prvotno namijenjenu općoj bolnici, od
1869. do 1879. iznajmljenoj tvornici duhana. Pošto je devastirana zgrada obnovljena i adaptirana, Akademski senat Sveučilišta traži da se ukloni stočno sajmište, a trg uredi kao javni park. Međutim, gradski je prioritet uredenje Prilaza i njegova spoja s Marovskom (Masarykovom) ulicom kroz prostran vrt Sveučilišta, koji će se morati znatno smanjiti. U odgovoru Akademskom senatu ipak se navodi da će se trg u budućnosti urediti kao perivoj i produljiti do željezničke pruge i „duž ove spojiti sa šetalištem priredjenim u produženju Zrinjskoga trga takodjer do iste točke, pa onda odstupiti sveučilištu Franje Josipa I u tom perivoju primjeren prostor za botanički vrt”. To je prva službena formulacija ideje uokvirenja središta grada perivojnim trgovima. Dokumentira je i nacrt Situacija jednog diela Zagreba od god. $1882^{21}$ (sl. 2).

Sljedeće, 1883. godine, u članku Osnova za uredjenje grada Zagreba (Narodne novine od 14. ožujka) u opisu nove regulatorne osnove kao glavna novost predstavljen je „estetički okvir” parkova oko središta grada. Detaljno su opisane njegove pojedine dionice i njihove atrakcije. Autor članka poziva se na ekskluzivnu informaciju iz Gradskog građevnog ureda: o osnovi se počelo razmišljati prije dvije godine - dakle, 1881., a o njoj raspravlja poseban odbor. Iz drugog izvora saznaje se da je taj odbor osnovan u siječnju 1883. godine. Sastoji se od vladinih eksperata Jurja Augustina, Josipa Altmanna i arhitekta Hermana Bolléa, predstavnika Gradskog građevnog ureda Ruperta Melkusa i Milana Lenucija te gradskih zastupnika Vatroslava Egersdorfera, Janka Nikole Grahora, Matije Mrazovića, Guida Pongratza, Janka Jambrišaka i Ivana Šviglina; izvjestitelj je senator Adolf Hudovski. To su prve vijesti o reviziji regulatorne osnove.

Gradnja vojarni još je 1874. bila uključena u strateški program realizacije najvažnijih gradskih potreba (vodovod, kanalizacija i premještanje potoka Medveščaka, komunalni uređaji i objekti, škole). Predviden je zajam od 2735 ooo forinti, od toga 620000 za tri vojarne. Motivi za gradnju vojarni bili su rasterećenje građanstva od zakonske obveze ukonačivanja stalne posade i jedinica u tranzitu, uopće izmještanje vojske iz užeg područja grada, ali i očekivanja prihoda od vojne potrošnje. No tek 1879., donošenjem Zakona o nastanjivanju vojske i, 1880. godine, objavom o razmještaju vojske u cijeloj državi stvoreni su uvjeti za gradnju. Iste godine utvrđene su lokacije: pješačke na 


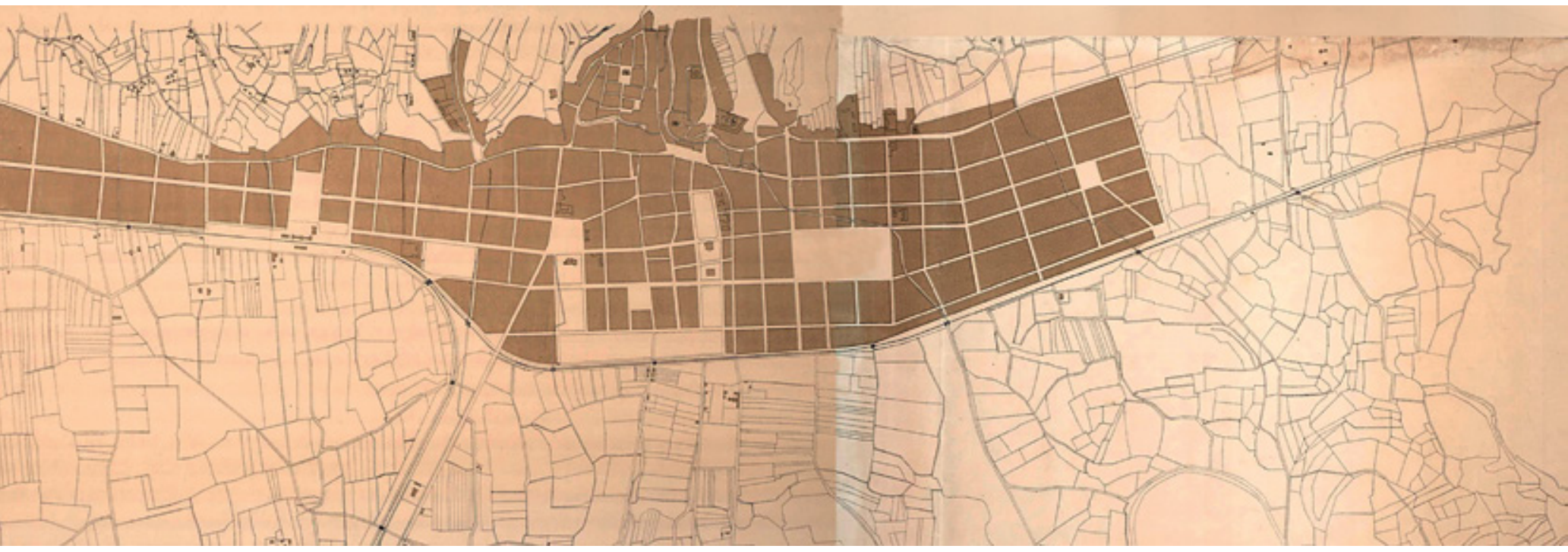

2 Situacija jednog dijela Zagreba, 1882.

HR HDA, Zbirka građevinskih nacrta, 905 ,

Regulacijske osnove, I-93

Plan of one part of Zagreb, 1882

Croatian State Archives, Collection of architectural

designs, 905, Regulatory plans, I-93

početku Savske ceste (na današnjem Rooseveltovu trgu), a topničke i konjaničke na neurbaniziranom području istočno od Draškovićeve ulice gdje je harao neregulirani potok Medveščak. Odustalo se od goleme vojarne, planirane 1865. i dala se prednost paviljonskom tipu koji zahtijeva mnogo veću površinu. Projekti su naručeni od uglednog bečkog arhitektonskog biroa Gruber \& Völckner, specijaliziranog za vojne gradnje. Projekt pješačke vojarne isporučen je već u kolovozu 1881., konjaničke 1882., a topničke tek 1884. godine. U spomenutom opisu nove osnove iz 1883. ističe se da se „velike kasarne” planirane „u razdalekih krajevih grada” moraju „cestama spojiti” i pledira za skorašnju izgradnju cesta. Riječ je o magistralnim prometnicama koje vojarne povezuju s postojećim Južnim kolodvorom. Tako je kretanju vojske („vojničkoj komunikaciji”) namijenjen potez Nova ulica (Hatzova - Trenkova - Žerjavićeva Vukotinovićeva) i Vojnička (I. Kršnjavoga). Druga magistrala protezala bi se Boškovićevom, Kukovićevom (Hebrangovom) i „produljenom Kukovićevom" (Klaićevom), dok bi treća vodila od Sajmišta (Trga Republike Hrvatske) do Vodovodne ulice: to je dijelom uredeni Prilaz. Cesta od Južnog kolodvora do klaonice (u današnjoj Bauerovoj ulici), duž pruge, služila bi „,poglavito za tjeranje blaga”. Većina tih komunikacija u smjeru istok - zapad planirana je u generalnoj osnovi (1865.), iako ne u tim duljinama, a sada su im utvrdene funkcija i neki elementi oblikovanja (drvoredi, predvrtovi). Dok ideja o perivojnom okviru, formulirana 1882. i uključena 1883. u prijedlog nove regulatorne osnove, nije izazivala prijepore, vojarne su sve do 1886. ostale problem zbog financiranja i postojanih pritisaka vlade da se troškovi reduciraju. Ujesen te godine vlada je odbacila lokaciju pješačke vojarne na početku Savske ceste s obrazloženjem da će se Sveučilištni trg, na kojem postoje kulturne i prosvjetne institucije, a dobit će i novo kazalište, ubrzo preobraziti u perivoj, pa ondje nema mjesta vojarnama. Lokacija je na brzinu pronađena početkom 1887. sjeverno od Južnog kolodvora, na mjestu gdje je bio predviden trg, i potom uključena u osnovu.

Osim vojarni još jedan od razloga otezanja dovršetka osnove bile su polemike o lokaciji novog stočnog sajmišta. Još 1885 . vlada zahtijeva da se ono ukloni sa Sveučilištnog trga te da se drugdje nade mjesto za njega. Iste godine bit će kupljeno prostrano zemljište između Draškovićeve ulice i klaonice, odnosno planirane topničke i 
konjaničke vojarne, uočeno još 1884 . godine. No vlada početkom 1887. odbacuje lokaciju utvrđenu prije prezentacije (i odobrenja) nove regulatorne osnove. Gradskoj vlasti predbacuje manipulaciju: „Sajmište udesiti i prilagoditi se ima glavnoj gradskoj regulatornoj osnovi, a ne obratno, da se regulatorna osnova sastavlja i prilagodjuje prema, u napred jur ustanovljenom mjestu sajmišta." U regulatornu osnovu to će zemljište biti uneseno kao Trg D - ipak kao stočno sajmište. Ondje će doista i biti otvoreno 1890., na Kraljevski sajam. U očekivanju premještanja potoka Medveščaka do 1892. bit će provizorno uređena velika površina, a trg 1896. preimenovan u Sajmište.

\section{Regulatorna osnova iz 1887.}

Prvi zahtjev za dopunu recentne regulatorne osnove potječe iz 1880. godine kada je okončan rad na geodetskom snimanju grada, što je još 1865 . bio uvjet za izradu mapa u odgovarajućem mjerilu. No to nije bio glavni motiv osnutka odbora za reviziju osnove, ${ }^{22}$ nego su to bile nove ideje i potrebe. Osim odbora, sastavljenog od ponajboljih eksperata, osnovom se poglavito bavio Gradski građevni ured. Kako je prethodno prikazano, do 1882. godine formulirani su novi elementi koji se po svojim dimenzijama i zamašnosti, a napose vrijednosnom usmjerenju nisu mogli karakterizirati „dopunom”. Zato se prijedlog osnove, objavljen 14. ožujka 1883., već predstavlja kao „novi tloris”, odnosno nova regulatorna osnova. Nije izvjesno koliki je udio u njoj imao odbor za regulatornu osnovu, imenovan tek tri mjeseca prije te objave, ali je temelj zacijelo osigurao Gradski gradevni ured. Različite okolnosti izazvale su promjene osnove iz 1883., pa se ona u odnosu na verziju iz 1887. može obilježiti kao prednacrt. Rad na osnovi kontinuirano je pratio odbor osnovan 1883., a u tom je procesu odredena uloga dopala vladi, odnosno vladinim ekspertima i političarima. Dok se autor prve osnove (1865.) može identificirati razmjerno pouzdano, za drugu je osnovu ispravnije ustvrditi da je kolektivno djelo. U njemu je ipak glavna uloga pripala gradskim činovnicima, $\mathrm{Ru}-$ pertu Melkusu i Adolfu Hudovskom - manje Milanu Lenuciju kojem se olako pripisivalo autorstvo, ${ }^{23}$ a uz njih i Jurju Augustinu, visokom vladinu činovniku, možda i Vatroslavu Egersdorferu, autoru prve osnove, a tada gradskom zastupniku. No diskusije o pojedinim elementima koje su se žustro i polemički vodile godinama svjedoče o pojedinačnom, često kritičkom angažmanu drugih članova i njihovu mogućem udjelu. Za razliku od svojih prethodnika i kolega, članova odbora za prvu osnovu koji su posebnim elaboratom legitimirali svoje obrazovanje, upućenost i svjetonazor, ovaj drugi odbor to nije smatrao potrebnim. Ograničio se na pragmatičnu interpretaciju zaključaka donesenih tegobnim raspravama i nategnutim konsenzusom.

Regulatorna osnova sastoji se od brošure Obrazloženje regulatorne osnove grada Zagreba i predlozi za odobrenje i provedenje iste, s nadnevkom 26. svibnja 1887. i rukopisnog nacrta. ${ }^{24} \mathrm{U}$ Obrazloženju se najprije navode tri gradska „razdiela”, područja ili zone različitih funkcija i različite razine razrade. Zoning je važno obilježje ove osnove koja obuhvaća mnogo veće područje nego osnova iz 1865., što senator Adolf Hudovski, izvjestitelj odbora, objašnjava „sadanjim razvitkom grada" (sl. 3).

Prvi razdjel obuhvaća središnje urbano područje: Donji grad kako je definiran u prvoj osnovi s izduženim ekstenzijama prema zapadu i istoku: sa zapada seže do potoka Černomerca, s istoka obuhvaća novi teritorij koji se predviđa pripojiti gradu, a sa sjevera Ilicu, Gornji grad (,do razkršća mlinarske ceste u Jurjevskoj ulici”), Novu ves, Kaptol s Ribnjakom i dio Vlaške ulice. Ta je zona nositelj centraliteta sa svim pripadajućim atributima. Drugi razdjel obuhvaća ruralno područje od željezničkih pruga do rijeke Save; treći područje sjeverno od Ilice, odnosno Vlaške ulice i Maksimirske ceste - „krasni gradski predjel”, buduću rezidencijalnu zonu s obilježjima vrtnoga grada. U drugi i treći razdjel uključeni su pojedini dijelovi Lašćine koju se predviđa pripojiti gradu. ${ }^{25}$

Razvoj se očekuje najprije u prvom razdjelu za koji je postavljena regulacija, a istekom procedure donošenja osnove za njega bi se izradila detaljna osnova (,u velikom mjerilu”). U drugom razdjelu postojeće ceste i putovi samo se ispravljaju i dopunjuju s „nekoliko ponajviše prečki prerezanih novih cesta", ali kako se ne predviđa njegova skorašnja izgradnja, velika ortogonalna mreža tek upućuje na tip urbanizacije. Predviđa se izvedba nasipa na Savi i regulacija potoka, plovni kanal od Rugvice na drukčijoj trasi nego u prvoj osnovi, luka i centralni kolodvor, dok bi se zemljište u okolici tog kolodvora i luke namijenilo skladištima, tvornicama i radničkim kućama, a osigurala i površina „za svrhe tržnoga prometa”. Na zapadnoj strani tog razdjela predviđen je ,posebni predjel za podizanje radničkih stanovah”, otprilike na 
mjestu gdje je u prvoj osnovi utvrden „Zaselak” (radničko naselje). Cijelo to prostrano područje i dalje se zamišlja kao industrijska zona. U trećem razdjelu planirane su nove ceste za poboljšanje kolnog prometa, ali i pješačke staze i stube za šetače. Naznačene su površine za proširenje javnih parkova i uredenje novih.

U osnovi su planirane 123 ceste (43 u prvom, 50 u drugom i 30 u trećem razdjelu), od toga 23 ceste u deficitarnom smjeru sjever - jug. Broj trgova i zelenih površina upućuje na sazrelu svijest o gradotvornom potencijalu javnog prostora i novu predodžbu grada uopće. U tome kao da se autori osnove ravnaju definicijom Josefa Stübbena: „Smještaj i uređenje javnih trgova predstavlja umjetnički najvažniju zadaću gradogradnje. Uspješno rješenje te zadaće pripada glavnim uvjetima za zadovoljavajuće oblikovanje grada.” ${ }^{26}$ Čak 30 trgova, odnosno parkova predviđeno je za sva tri razdjela ( 19 u prvom, 5 u drugom i 6 u trećem). U prvom se najavljuje parkovni okvir središta istim riječima kao u prednacrtu regulatorne osnove iz 1883. i navode nazivi njegovih dijelova, tj. triju prospekata: istočni, zapadni, južni perivoj i botanički vrt. Osim tog monumentalnog ansambla planira se uređenje dvaju postojećih trgova, Jelačićeva i Kaptolskoga, te otvaranje 13 novih trgova, obilježenih slovima: trga A, na mjestu insule južno od pravoslavne crkve; B, u Novoj Vesi ispred crkve sv. Ivana; D i E, istočno od Draškovićeve; F, na prometnoj magistrali duž budimpeštanske pruge; $G$, na središnjoj osi Donjega grada, uz Preradovićevu ulicu; $\mathrm{H}$, na raskršću Primorske i Prilaza; J, na Prilazu baruna Filipovića; L, ispred zgrade zapovjedništva pješačke vojarne u osi Prilaza; M, na Savskoj cesti, N, na raskršću Savske i Vojničke ceste (danas Izidora Kršnjavoga); O, u Ilici na stjecištu Pantovčaka i Rokove ulice te na Ciglani (danas Srednjoškolsko igralište Elipsa). Parkovi se pak predviđaju na neuredenim površinama otprije namijenjenima trgovima, kao što su Nadbiskupski trg, na kojem bi se uredilo dječje igralište, dok bi se na mjestu kanoničkih vrtova u Nadbiskupskom vrtu $(\operatorname{trg} C)$ uredio javni perivoj i još jedno igralište, a javni perivoj na dijelu velikog trga ispred Južnog kolodvora (trg K).

Za II. razdjel, buduću industrijsku zonu, također su predviđeni trgovi: $\mathrm{P}$, istočno od Savske ceste; $\mathrm{R}$, u predjelu za radničke stanove; $S$, na mjestu pašnjaka u selu Horvati; T, na mjestu pašnjaka u selu Trnje i U, na Tratinskoj cesti na Trešnjevki. Parkovi nisu planirani, no u III. razdjelu, u sjevernoj rezidencijalnoj zoni, predvidaju se samo parkovi i šetališta; uređenje sustava parkova „u Tuškancu kraj Streljane, kraj Sofijina puta, na ravnu nad šumom” i uređenje "perivoja i šetališta na Cmroku”. Stara groblja sv. Roka i sv. Jurja, s vremenom napuštena pošto je 1876. na Mirogoju otvoreno novo središnje groblje, pretvorila bi se u javne perivoje, a ispred mirogojskog groblja uredio bi se novi park. Napokon na „bregu Kalvariji”, zaravni Šalate, predviđa se veliko igralište za djecu i park. U posljednjem članku regulatorni odbor naglašava i preporučuje „da bi se prešnom izjavila nabava šumah, odredjenih za javna šetališta, isto tako neka bi se što skorije nabavile površine na Ribnjaku i na Kalvariji, potrebite za javne perivoje”.

U Osnovi se detaljno navode lokacije za javne zgrade: najprije za vojarne i škole ${ }^{27}$ na kraju i za „druge”. Tako se medu potonjima ponovno javlja lokacija kazališta u Ilici, poslije višestruko osporena javnim raspravama i na kraju odbačena; ponavlja se i stara ideja o premještanju gradske vijećnice u bolnicu milosrdne braće na početku Ilice, neposredno pokraj budućega kazališta (!), a bolnica se predviđa na Kalvariji (Šalati). Župnoj crkvi sv. Blaža namijenjeno je mjesto na uglu Prilaza i Primorske ulice, gdje je napokon nakon dugih diskusija i sagrađena; sirotištu mjesto na Josipovcu (Ulica Ivana Gorana Kovačića i dio Nazorove) koji se sljedećih godina regulira i izgrađuje te tržnicama na trgu A (Preradovićevu) i u Jurišićevoj ulici. Kupališta bi se uredila na Savi, između mostova i u Ksaverskoj dolini, na potoku Medveščaku, a „toplo kupalište s vodom od vodovoda" nedaleko od Južnog kolodvora i pokraj planiranog radničkog naselja.

Najavljeni su i veliki komunalni projekti, opisani u članku Vodogradnje: kanalizacija, premještanje potoka Medveščaka i regulacija potoka. Za kanalizaciju je već izrađen generalni projekt sa smjernicama za realizaciju, a u njegovu je sklopu projekt za uklanjanje Medveščaka iz urbanog područja. Potok Černomerec regulirao bi se i osigurao nasipima, dijelom ustavama. Ostali se potoci u svojem gornjem toku i do željezničkih pruga neće moći premjestiti, ali bi se regulirali ili presvodili. Južno od željezničke pruge za potok Kuniščak i druge potoke izveo bi se sabirni kanal, spojio s potokom Medveščakom i odveo do Save. Posebno se naglašava potreba razdvajanja otpadnih voda i potoka, u kojima se u budućnosti želi čista voda. Za plovni kanal od Rugvice, luku i kanal koji bi je napajao vodom utvrđena je lokacija, dovoljno 


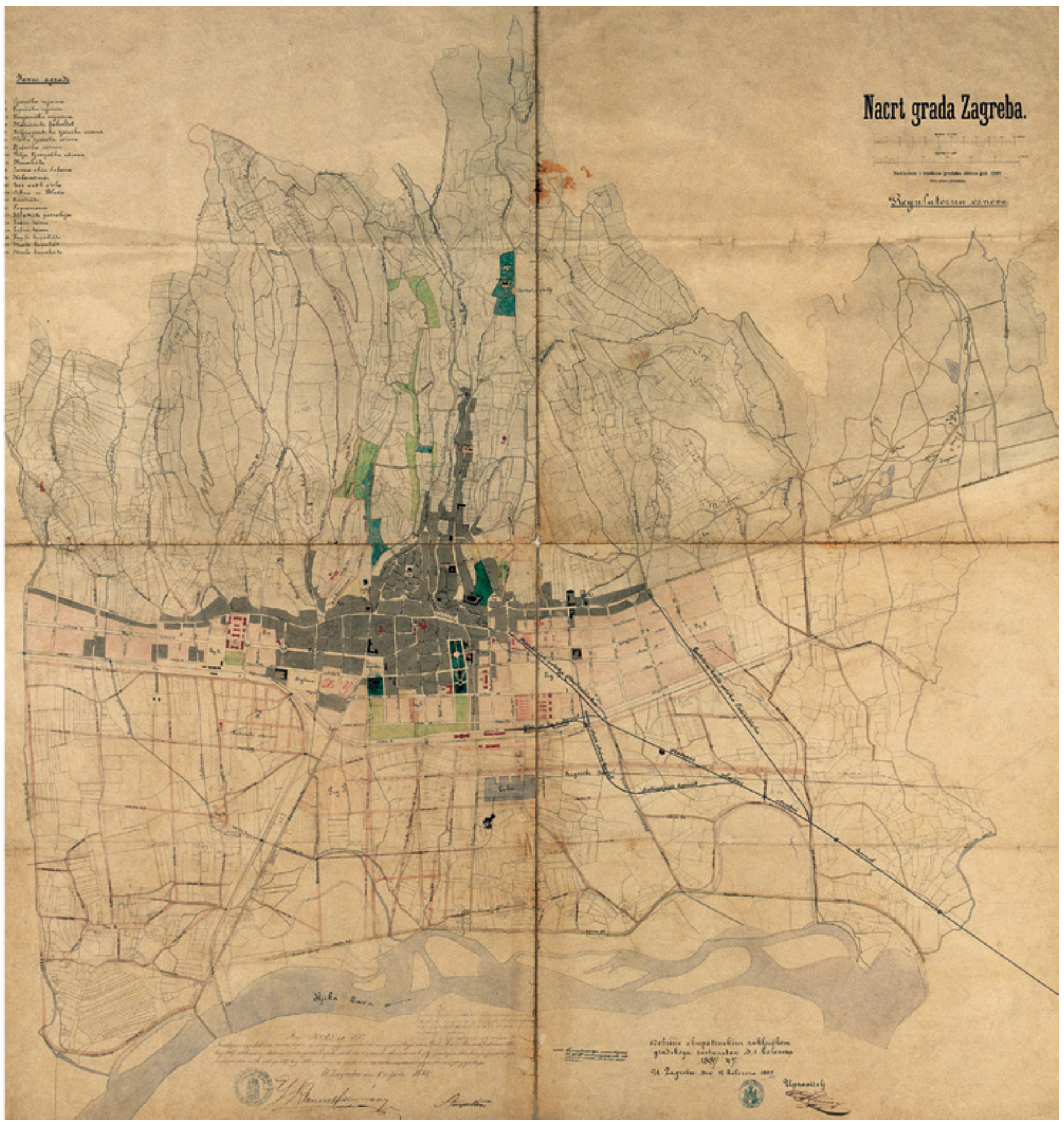
MGZ, Zbirka planova, br. 29689

The second regulatory plan of Zagreb, manuscript original, 1887 Zagreb City Museum, Plans Collection, n. 29689 


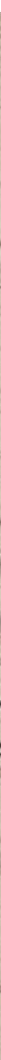

4 Shema cesta duž željezničkih pruga i prijelaza u regulatornoj osnovi 1887.

Crveno pruge, plavo ceste; plave kružnice postojeći prijelazi, crvene kružnice novi prijelazi, žute kružnice ukinuti prijelazi. Intervencija Sanja Štok, d. i. a.

Road scheme along railway tracks and crossings in the 1887 regulatory plan

Red - railway tracks; blue - roads; blue circles - existing crossings; red circles - new crossings; yellow circles - former crossings. Graphical intervention by architect Sanja Štok

prostrana za gradnju skladišta (,otvorenih i gradjenih”). Kanal se ne bi gradio na trošak grada, nego bi se povjerio posebnom društvu (,ako se takovo nadje").

U članku Posebne odredbe utvrđene su dimenzije izgradnje (katnost kuća): u I. razdjelu dvokatnice, na trgovima trokatnice, u drugim ulicama i dijelovima grada najmanje jednokatnice, a prizemnice će se dopustiti u II. i III. razdjelu. U Tuškancu i na Sofijinu putu (Dubravkinu) ne dopušta se gradnja kuća, kao i ondje gdje nema ulice ili ceste, a zabranila bi se gradnja na krajevima grada, istočno od Klaoničke (Bauerove) i zapadno od Vodovodne ulice. Tvornice (,sa slabijimi zidovi ili sa stjenami u kanatih") mogu se graditi u II. i III. razdjelu, iznimno u I. razdjelu, zapadno od Južnog kolodvora i istočno od Klaoničke ulice i trga E, na gradskoj medi. „Nečiste” tvornice neće se tolerirati u I. i III. razdjelu, a u II. razdjelu mogu se podizati samo južno od pruga i istočno od ceste $63 \mathrm{u}$ Trnju. Napokon, za sve ceste i ulice najavljuju se detaljne regulatorne osnove.

\section{Prema novoj generalnoj regulatornoj osnovi?}

Prije donošenja druge regulatorne osnove utvrdenjem urbane trase budimpeštanske željeznice (dionice Nagykanizsa - Zákany - Zagreb) 1868. godine nastala je fatalna hipoteka za razvoj grada i urbanističko planiranje. Njome će se od 1896. intenzivno baviti Milan Lenuci, od 1891. predstojnik 
Gradskog gradevnog ureda i 1907. ponuditi rješenje. Lapidarno tu hipoteku opisuje 1909., dok se još vodi borba za predloženo rješenje: „Pruga Budimpešta - Zagreb gradjena je koncem šezdesetih godina na kilometar od središta grada, gradjena je u niveau-u cesta, koje je presjekla, ponajglavnije Petrinjsku ulicu i Savsku cestu. Stvorena je prva zapreka razvoju grada prema Savi, gradnja se izvela unatoč prosvjedu gr. općine, koja je u tom, već onda nazrijevala štetu i pogibao, koju danas zaista i čini." U regulatornoj osnovi iz 1887. nastojalo se zapreku komunikaciji Donjega grada s područjem do Save prevladati uvodenjem cesta sjeverno i južno od pruge te s više prijelaza (sl. 4). No gradnjom kolodvora (otvorenog 1892.) i strojarske radionice (većim dijelom u pogonu od 1894. godine) zapreka se znatno povećala. Stoga je 1895. Ministarstvu trgovine upućen zahtjev da se pruga premosti u Preradovićevoj ulici na prijelazu koji je satima zatvoren zato što se ondje ranžiraju vlakovi. Sljedeće, 1896. godine, Milan Lenuci izrađuje projekt vijadukta (izmedu Preradovićeve/Haulikove i ulice 41/Kumičićeve) koji ne nailazi odaziv do 1902. godine.

Godine 1899. vlada upućuje Gradskom poglavarstvu zahtjev za izradu nove generalne osnove i šalje elaborat svojeg Gradevnog odsjeka koji bi u tome imao pripomoći. Od elaborata su se očuvala tek dva lista: prvi, naslova Generalna osnova o budućem razvitku grada Zagreba. Ceste i željeznice oko Zagreba, i drugi, Predlog za budući razvitak Zagreba. ${ }^{28}$ Elaboratom se predviđa urbanizacija područja južno od željezničke pruge sve do rijeke Save (Trnja): „budući nutarnji dolnji grad”, dakle, proširenje Donjega grada. Spajanje tih dvaju područja omogućuje se novim rješenjem tzv. željezničkog čvora. Ono je jasno prikazano na drugom listu: ukidaju se pruge između Južnog i „državnog” (glavnog) kolodvora i njihov spoj („delta”) na Savskoj cesti; pruge se vode novim trasama, znatno razmiču i spajaju neposredno do rijeke, na Savskoj cesti. Za područja zapadno $\mathrm{i}$ istočno od Savske ceste (Trešnjevku i Trnje), tj. novi dio grada, predviđa se pravilna ortogonalna ulična mreža, no mnogo većih dimenzija nego u Donjemu gradu. Na drugu važnu pretpostavku tog proširenja gradskog teritorija, a to je regulacija Save, upućuje širok, ravan potez rijeke uz čije se nasipe proteže nova trasa budimpeštanske pruge (sl. 5). Prvi list prikazuje cijeli prometni sustav i novi tok rugvičkog kanala, u Trnju smješta teretni i ranžirni kolodvor, povezan s putničkim, ali nije naznačeno rješenje željezničkog problema prikazano na drugom listu. No ono je moglo potaknuti Lenucija da 1902. odustane od vijadukta i razmotri mogućnosti koje je otvorio vladin elaborat. Jedna je bila znatno podizanje pruga i „tla kolodvorskoga" tako da se ispod njih mogu provesti ceste; druga, preuredenje kolodvora $u$ zaglavni, nova trasa pruge koja bi se izvela s njegove istočne strane, provela „u ravnici izmedju sadanjih pruga i Save" i ondje spojila s prugom i kolodvorom Južne željeznice (Novo Mesto - Zagreb - Sisak). Navodi da bi to bili tehnički složeni i skupi zahvati, a i to da urbanizacija područja od pruga do Save nije zasada poželjna. Potaknuta sve većim interesom za gradnju kuća, vlada 1904. ponovno zahtijeva izradu regulatorne osnove upravo za to područje. Lenuci opširno odgovara i nabraja protuargumente: potrebno je regulirati Savu i potoke, ukloniti barijeru što je čine nisko položene pruge, odnosno izvesti nove; utvrditi mjesto ranžirnog kolodvora i nove pruge koja bi spajala samoborsku i državnu (budimpeštansku) željeznicu te lokaciju savske luke, a problem je i izrada novih katastarskih mapa, odnosno izmjera cijeloga gradskog teritorija. Nadalje navodi da područje od pruga do Save zbog topografskih obilježja nije prikladno za rezidencijalnu namjenu i da bi kanalizacija za njega bila mnogo skuplja od one u Donjemu gradu i drugdje. ${ }^{29}$

Ali 1906., prigodom rasprave o nadasve nepovoljnoj lokaciji ranžirnoga kolodvora, utvrđenoj $\mathrm{u}$ direkciji Mađarske kraljevske željeznice u $\mathrm{Bu}$ dimpešti, Lenuci će upozoriti: „Ne bi bio kolodvor ništa drugo, no samo nastavak i produljenje postojećega državnoga kolodvora, razstavljen od njega paralelnim kolotečinama na dva kilometra duljine (...) Na tim bi kolotečinama občili neprestano svi teretni vlakovi te bi sav prostor izmedju jednoga i drugoga kolodvora, pošto su kolotečine u niveauu sadašnjih cesta - što se drugdje danas više ne čini - bio za kolni i osobni promet preko željezničke pruge bitno spriečen i gotovo zatvoren, a grad Zagreb koji je već sad željezničkim prugama na $3 \mathrm{klm}$ u izgradjenom djelu presječen, bio bi u buduće na duljini od $7 \mathrm{klm}$ podpuno zatvoren kao okovan željeznim kolobarom.” Štoviše, navodi, grad je težio razvoju južnih područja, ali ga je u tom priječio neriješeni željeznički problem. Zahtjevi za gradnju industrijskog kolosijeka potiču, pak, vladu da iste godine ponovno inzistira na hitnoj prostornoj definiciji industrijske zone - „predjela za tvornice”. Sljedeće, 1907. godine 


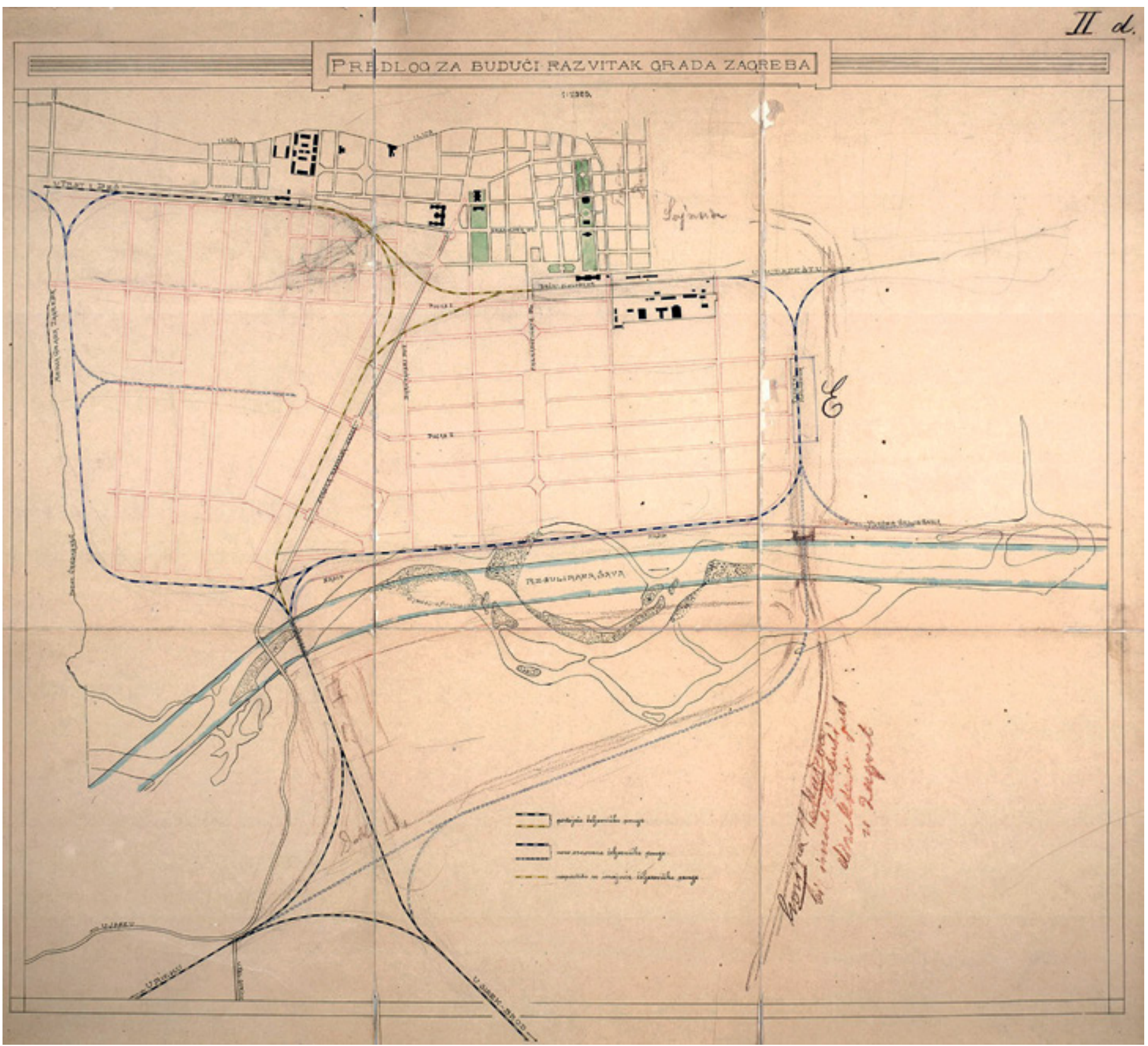

5 Studija generalne regulatorne osnove 1898. Drugi očuvani list II. D HR HDA, Zbirka građevinskih nacrta, 905, Regulacijske osnove, I-89

Study for the 1898 general regulatory plan. Second preserved sheet II. D

Croatian State Archives, Collection of architectural designs, 905, Regulatory plans, I-89 povećavaju se pritisci ponovno zbog neriješene lokacije ranžirnog i teretnog kolodvora. Napokon, nakon stručne anketne rasprave i ekspertize $\mathrm{Hr}$ vatskog društva inžinira i arhitekata Lenuci podnosi prijedlog rješenja krucijalnog problema elaboratom koji se sastoji od nacrta Osnova za budući razpored željezničkih uredaba i tekstualnog priloga s obrazloženjem. Bit rješenja naznačio je još 1902. radikalnom alternativom $i$ sada ga doradio. Oba se kolodvora preureduju u zaglavne, iz njih se izvode nove trase željezničkih pruga koje se znatno razmiču sa zapada i istoka te vode do svojega novog spoja južno od Save. Iz urbanog područja, 


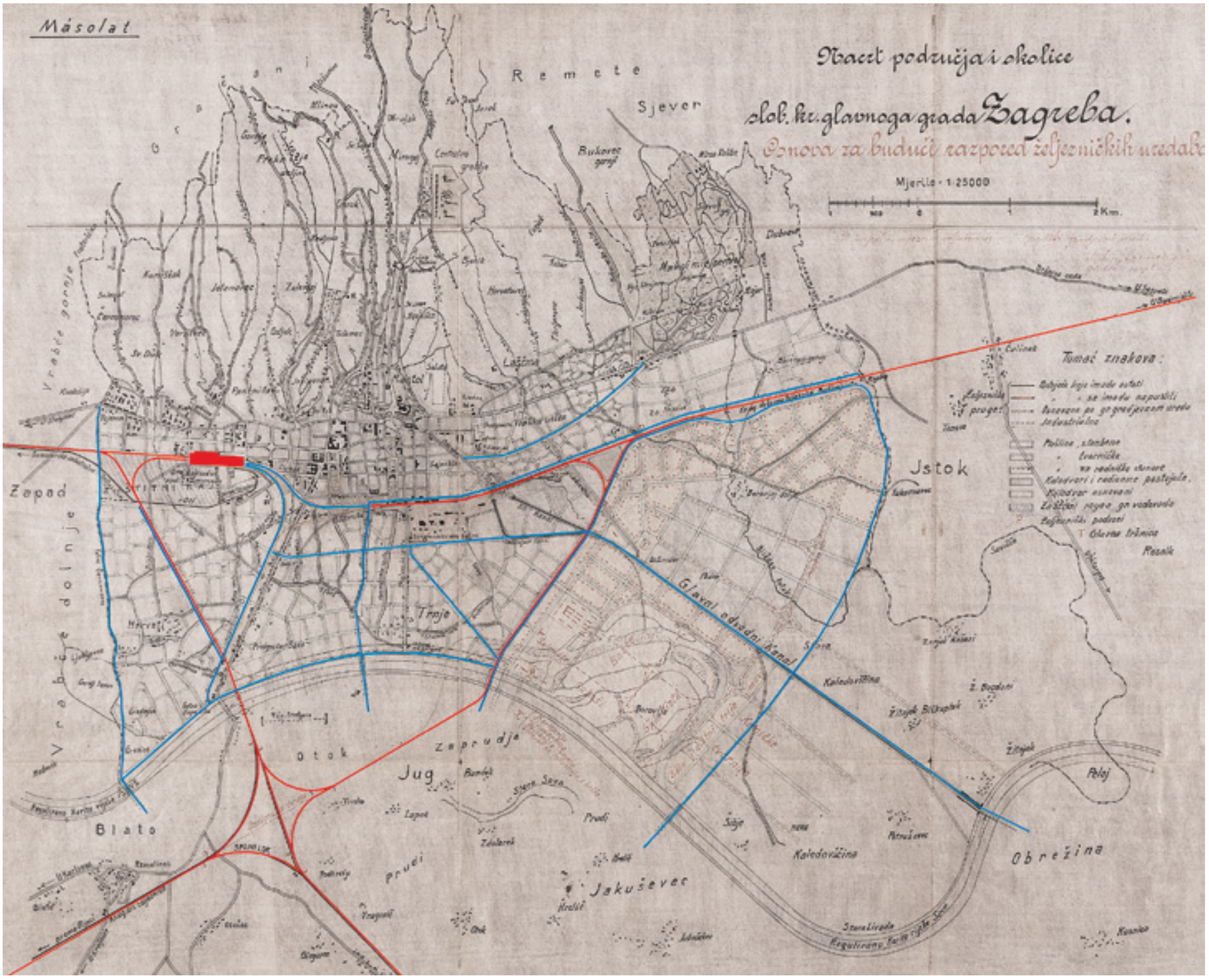

izmedu kolodvora, uklanjaju se pruge i njihov spoj („,delta”, „triangl”), pa urbanizaciji južnog područja do Save na putu više ne stoji ništa, a stari i novi dio grada (u Trnju i na Trešnjevci) mogu se spojiti. U oslonu na taj prijedlog Lenuci rješava i sve druge probleme: utvrđuje lokacije ranžirnog i teretnog kolodvora, industrijskih pruga, spoja vicinalne (samoborske) željeznice s postojećim prugama, novu cestovnu mrežu te formira golemu industrijsku zonu s lukom i plovnim kanalom na istoku grada ${ }^{30}$ (sl. 6). Iako je sam Lenuci svoju osnovu nazvao „škicom”, ona pristupom i dimenzijama predstavlja Zagreb kao modernu
6 Milan Lenuci, Skica generalne regulatorne osnove Zagreba, 1907.

Shema komunikacija: željezničke pruge crveno, ceste plavo. Intervencija Sanja Štok, d. i. a. HR DAZ, GPZ GO sign. 58

Milan Lenuci, Sketch of the general regulatory plan of Zagreb, 1907

Communications scheme: red - railway tracks; blue - roads. Graphical intervention by architect Sanja Štok Zagreb State Archives, GPZ GO sign. 58 
metropolu. Njegovo rješenje krucijalnog urbanističkog problema Zagreba odbačeno je zbog političkih i materijalnih razloga. Hipoteka je ostala do danas, iako ju je nastojala riješiti modernistička regulatorna osnova prihvaćena 1938., u osvit Drugoga svjetskog rata zbog kojega nije dospjela do realizacije.

\section{FACIT}

Trajnim legatom dviju osnova iz 19. stoljeća ostaju urbanističko-arhitektonska cjelina Donji grad i dva velika, realizirana urbana projekta u Donjemu gradu i sjevernom rezidencijalnom predjelu: slijed trgova parkova uokolo užeg središta grada, tzv. Zelena potkova, i razvedena parkovna zona koja obuhvaća Tuškanac, Kraljevac, Zelengaj i Cmrok, Rokovo šetalište i Jurjevsko groblje te park-šumu Orlovac. Suvremeni pojam „urbani projekt” tu je za njih u punom smislu riječi na mjestu: riječ je o dugoročnom planu, realiziranom udjelom javnih i privatnih sredstava. Javna, gradska investicija naišla je na odaziv privatnika i višestruko se oplodila. Tako je uređenje perivoja na zaravni Tuškanca 1891./1892. dalo zamah izgradnji prve zagrebačke četvrti vila (Cottage-Viertel) na tadašnjem Josipovcu, a slično se dogodilo na Rokovu brijegu nakon 1910. kad se počinje formirati park, a na njegovim obodima mala kolonija vila s umjetničkim atelijerima. Uređen i već razveden tuškanački park poticao je u prvom, a napose drugom desetljeću 20. stoljeća niz detaljnih regulacija s parcelacijama dotadašnjih velikih posjeda i majura, prema kojima duž ulice Tuškanac nastaju izboji: Gvozd, Jabukovac, Vijenac, Paunovac, Slavujevac, koji već svojim nazivima obilježavaju tu sredinu vila, ljetnikovaca i vrtova kao urbano-ladanjsku idilu. Duž tih ulica nanizat će se uskoro najbolja ostvarenja protagonista protomoderne i moderne arhitekture. Svaki sastojak te parkovno-rezidencijalne zone steći će stapanjem topografskih specifičnosti, arhitekture i vrtne umjetnosti prepoznatljivu fizionomiju, na čemu se zasniva doživljajno bogatstvo tog „krasnog gradskog predjela”, kako se 1887. naziva u osnovi.

Ta dva urbana projekta, a i treći: Mirogoj, koji se ne povezuje s regulatornom osnovom iz 1887. zato što je otvoren još 1876., predstavljaju baštinski kapital na kojem će Zagreb razvijati svoju fizionomiju i svoj urbani identitet. Lenucijev prijedlog, sadržan u ,škici” iz 1907., ostaje, pak, zalogom za budućnost koja se s obzirom na dosadašnja rješenja i ideje još ne nazire.

\section{BILJEŠKE}

1 Mirjana Gross donosi najopćenitiju definiciju modernizacije za razdoblje preobrazbi svih područja života koje dovode do građanskog društva. Ovdje se upotrebljava za drugu polovinu 19. stoljeća, sve do 1914. godine.

Mirjana Gross, Počeci moderne Hrvatske. Neoapsolutizam u civilnoj Hrvatskoj i Slavoniji 1850-1860. (Zagreb: Globus, 1985.)

2 Lelja Dobronić, Stari planovi Zagreba (Zagreb: Urbanistički zavod grada Zagreba, 1961.); ponovljeno pod naslovom „Širenje Zagreba," u Graditelji i izgradnja Zagreba u doba historijskih stilova (Zagreb: Društvo povjesničara umjetnosti SR Hrvatske, 1983.); Lelja Dobronić, „Izgradnja Zagreba u devetnaestom stoljeću," Vijesti muzealaca $i$ konzervatora Hrvatske 11 (1962.), 144-159; ponovljeno u Graditelji i izgradnja Zagreba u doba historijskih stilova (Zagreb, 1983.), 161-186; Eugen Franković, „Uloga Hermanna Bolléa u urbanističkom planiranju," Život umjetnosti 26/27 (1978.): 40-47; Eugen Franković, , Regulatorna osnova Zagreba iz 1865. godine," Život umjetnosti 32 (1981.): 48-59; Olga Maruševski, „Grad za pedeset tisuća stanovnika," Kaj 1 (1983.): 49-63; Olga Maruševski, Iso Kršnjavi kao graditelj (poglavlje „Izgradnja Zagreba”) (Zagreb: Društvo povjesničara umjetnosti SR Hrvatske, 1986.), 220-224.

3 Nalazila se u svežnju O odstranjenju prometnih zapreka, HR, DAZ, GPZ GO, sig. 58. Snješka Knežević, „Regulatorna osnova Milana Lenucija za dio Zagreba od željezničke pruge do rijeke Save iz godine 1907.," Radovi Instituta za povijest umjetnosti 16 (1992.): 169-197.

4 O tome opširno: Gerd Albers, Entwicklungslinien im Städtebau. Ideen, Thesen, Aussagen 1875-1945. Texte und Interpretationen (poglavlje „Organisation der Planes”), (Düsseldorf: Bertelsmann, 1975.); Gerd Albers, Zur Entwicklung der Stadtplanung in Europa (poglavlje „Plantypen”) (Braunschwig, Wiesbaden: Birkhäuser, 1997.), 254-257.

5 „Carski patent od 7. rujna 1850, kojim se odobrava i u kriepost stavlja privremeni občinski red za kraljevski grad Zagreb."

6 Za prvu fazu autorica se koristi pojmom „modernizacija izvana”, a pojmom „modernizacija iznutra” za drugu, kada razvoj potiču autohtone snage.

7 Riječ je o geodetskoj snimci terena buduće urbanizacije. Ta snimka nije izrađena za regulatornu osnovu 1865., zbog čega je Hrvatska dvorska kancelarija tek načelno prihvatila taj dokument uz zahtjev da se izradi naknadno.

8 Pripreme za gradnju pruge Zagreb - Sisak traju od 1850. i aktualiziraju se 1857., kada je otvorena magistralna pruga Beč - Trst. Zbog krize nakon pada neoapsolutizma, od 1859. do 1862., oteže se gradnja odavno planirane pruge Zidani most - Zagreb. Ta pruga i njezin kolodvor (Južni, poslije Zapadni) predani su na uporabu 1. listopada 1862. godine.

9 HR DAZ, GPZ, GO, sgn. 147 (rasprava i pritužbe); HR DAZ, GPZ GO, sgn. 50: za problem povezivanja kolodvora i grada formiran je „odbor ad hoc”, koji je gradskoj skupštini iznio svoj prijedlog o otvaranju ceste 24. i 25. veljače 1861. godine.

10 Plan je u mjerilu 1 : 1576 hv izradio Dragutin Albrecht ,pomoćju g. gradskoga mjernika”, kako se navodi na njemu, a u povodu održavanja Gospodarsko-šumarske izložbe 1864. godine. Zasnovan je na mapama prve katastarske izmjere cijele države, izvedene od 1853. do 1864. - MGZ, 5676; Kriegsarchiv, Beč, C VII, 4736; Geografski institut u Zagrebu, 37371-VIII-5. Mjernik je u to doba bio Janko Nikola Grahor.

11 Dovršena je 1. siječnja; gradskoj skupštini predstavljena je na četirima sjednicama u siječnju i dopunjena 23. ožujka; 20. svibnja odaslana je na uvid i razmatranje Namjesničkom 
vijeću (vladi), koja ju je 6. kolovoza proslijedila Hrvatskoj dvorskoj kancelariji u Beč kao najvišoj instanciji; potonja ju je odobrila 6. rujna 1865. godine.Istodobno su odobrene regulatorne osnove slobodnih kraljevskih gradova: Karlovca, Križevaca, Koprivnice, Požege i Osijeka te gradova i kotara Rijeke i Bakra. HR HDA, NV 146.

12 Inženjer Vatroslav (Ignjat, Ognjen, Žiga) Egersdorfer (Varaždin, 1819. - Zagreb, 1884.) završio je Visoku tehničku školu u Budimpešti; prije imenovanja u odbor za regulatornu osnovu bio je zaposlen u Zemaljskoj građevnoj direkciji, Građevinskom uredu Zagrebačke županije i Gradskom građevinskom uredu te bio potvrđen i cijenjen u struci. U tehničkom odboru najprije je bio izvjestitelj, a nakon Bouffleurova odlaska preuzeo je njegovu funkciju.

13 Barun Leonard Zornberg de Gallwitz (Galicija, 1803. - Zagreb, 1885.) bio je 1850. zadužen za osnutak C. kr. zemaljske građevne uprave, 1850. bio je njezin načelnik, a od 1851 . do umirovljenja 1876. vrhovni građevni nadzornik (nadinspektor).

14 Adolf Hudovski (Bjelovar, 1828. - Zagreb, 1900.). Diplomirao je 1848. na Mudroslovnoj akademiji u Zagrebu, od 1853. predavao u gimnaziji; 1859. u gradskoj službi; 1861. imenovan senatorom za financije. Postavio modernu organizaciju komunalnih službi, sudjelovao u izradi i realizaciji regulatornih osnova iz 1865. i 1887., izrađivao pravilnike, statute, elaborate, a 1894. izradio Osnovu građevnog reda. Autor je prvog vodiča Zagreba Zagreb i okolica, kažiput za urodjenike $i$ strance, 1892 . godine.

15 HR HDA, NV kut. 146 (Obrazloženje), HR DAZ, GPZ GO sgn. 50 (Zapisnik i Izvadak). Albrechtov plan iz 1864. s regulacijom: MGZ Zbirka planova, inv. br. 1878 (jedini primjerak osnove s oba lista; na prvom su listu ucrtane kasnije intervencije. NSK, Geografska zbirka, X-H-J-24 (samo list s područjem do pruge). Za ovaj prikaz spojen je prvi (gornji) list iz NSK-a s drugim (donjim) listom iz MGZ-a. Regulacija je ucrtana crvenom bojom.

16 Hrvatski hvat prema terezijanskom propisu iz 1756. iznosi 1,8965 metara, a četvorni hvat 3,596712 četvornih metara.

17 Savskom plovnom putu pridaje se osobita važnost, zato što bi se povezao s prugom Zemun - Rijeka is Podunavljem. Na banskoj konferenciji o željeznicama od 20. do 22. kolovoza 1862. ta je pruga identificirana kao okosnica hrvatskog željezničkog sustava, a Zagreb kao njegovo „sredotočje”. Autorima osnove morali su biti poznati zaključci te konferencije koja uz ostalo afimira i ideju Zagreba kao glavnoga grada i nacionalnog centra, formuliranu u doba ilirskog preporoda.

18 Rupert Melkus (1833. - 1891.). Diplomirao na Visokoj tehničkoj školi u Beču; od 1855. do 1857. radio kao geometar, 1868. imenovan je pripravnikom u vladinu Građevnom ravnateljstvu, a neposredno nakon toga županijskim inženjerom u Požegi. Godine 1869. izabran je za gradskoga inženjera u Zagrebu, a 1882. imenovan nadinžinirom.

19 Mirko (Emerik) Halper Sigetski ( Varaždin, 1830. - Zagreb, 1896.) bavio se kao savjetnik većim projektima: bio je povjerenik za narodno kazalište i uređenje zaklade baruna Eduarda Jelačića Bužimskoga, a s time u vezi za osnutak Zemaljskog sirotišta i tzv. cottage-četvrti na Josipovcu; kao predstojnik Gospodarstvenog odsjeka pokrenuo je niz gospodarskih i poljoprivrednih projekata. - Područjem južno od Trga Nikole Šubića Zrinskoga bavio se 1876. u studijama o smještaju Botaničkog vrta i inženjer Srećko Jacomini (Varaždin, 1830. - Zagreb, 1892.), u to doba predstojnik Arhitektoničkog odjela vladina Građevnog odsjeka.

20 Juraj Augustin (Zagreb, 1833. - Zagreb, 1917.). Obnašao dužnost predstojnika od 1876. do 1917. godine. Zaslužan je za modernizaciju građevinske struke, izgradnju željezničke mreže, razvoj mostogradnje, niskogradnje i visokogradnje. Bio je prvi predsjednik Družtva inžinira i arhitekta. Na margini nacrta navedeni su ovi sadržaji: „Sveučilište, Fizikalni kabinet, Botanička predavaonica, Kemički laboratorij, $\mathrm{Mu}$ zej, Realka, Obrtničko-trgovačka škola, Palača Pravosudja, Akademička sgrada, Botanički vrt i Javna pohadjališta.”

21 HR HDA, Zbirka građevinskih nacrta, 905, Regulacijske osnove, I-93.

22 Članovi odbora bili su inženjeri Vatroslav Egersdorfer (autor osnove iz 1865.), Kamilo Bedeković, Josip Siebenschein i Marcel Kušević.

23 Opširno o tome Snješka Knežević, „Lenuci i 'Lenucijeva potkova'," Radovi Instituta za povijest umjetnosti 18 (1994.): 169-189; Snješka Knežević, Zagreb Grad, memorija art (poglavlje „Post scriptum Lenuci onkraj Potkove”) (Zagreb: Meandarmedia, 2011.), 25-47.

24 HR DAZ, GPZ GO sgn. 50 (brošura); MGZ, Zbirka planova, inv. br. 29689. Gradskoj skupštini osnova je predstavljena 6. lipnja, prihvaćena na njezinoj sjednici 1. kolovoza i odobrena od Zemaljske vlade 8 . veljače 1888. godine. Prema rukopisnom originalu izrađen je 1889. nešto pojednostavljen nacrt ista naziva Nacrt grada Zagreba. Regulatorna osnova i tiskan u velikoj nakladi. Po toj mnogo poznatijoj varijanti osnova se često pogrešno datira 1889. godinom.

25 Laščina je uključena u gradski teritorij tek Banskom naredbom od 17. prosinca 1899. na temelju zakona o „razširenju teritorijalnog obsega glavnoga zemaljskoga grada Zagreba" od 11. travnja 1899. godine. Prema toj naredbi Zagrebu je pripojena porezna općina Laščina s Maksimirom, a 1. siječnja 1900. osniva se nova porezna općina Žitnjak, sastavljena od dosadašnje porezne općine Resnik i sela Borongaj, Petruševec i Vukomerec.

26 Josef Stübben, Der Städtebau (Darmstadt, 1890.), 189.

27 Za topničku i konjaničku vojarnu ostaje već prije utvrđeno mjesto na neurbaniziranom području istočno od Draškovićeve ulice, dok je za pješačku određeno novo, netom pronađeno mjestu na uglu Ilice i Kolodvorske ulice (Ulice Republike Austrije). Za vozarsku vojarnu adaptirala bi se postojeća topnička vojarna u Vlaškoj ulici. I za škole se uglavnom zadržavaju već predložene lokacije, a za budući medicinski fakultet predlaže mjesto u Palmotićevoj ulici.

28 HR HDA 148, SB To kut. 149. Prvi list nosi oznaku II. C. i broj pripadnog dokumenta, 45.187; drugi samo oznaku II. Franković prvi nacrt (II. C.) pogrešno pripisuje Milanu Lenuciju. Vidi: Eugen Franković, „Lenucijeva era,” Arhitektura 41 (1988.), 81-111.

29 Nakon premještanja Medveščaka (1898.) i pripajanja Laščine (1900.) Lenuci se koncentrira na urbanizaciju istočnog dijela grada. Iz 1905. potječu osnova za regulaciju prostranog područja od Draškovićeve ulice do Maksimira i dvije varijante za njegov dio (između Vlaške i željezničke pruge, danas Trg žrtava fašizma). U obrazloženju tih regulacija Lenuci iznosi argumente protiv urbanizacije južnih područja grada (napose Trnja) i zalaže se za uređenje područja sjeverno od pruga. Opširno o tome: Eugen Franković, „Regulatorna osnova istočnih područja Zagreba. Prilog poznavanju urbanizma na prijelazu stoljeća," Zbornik za narodni život i običaje Južnih Slavena 49 (1983.), 245-274.

30 Opširni opis i analiza: Knežević, „Regulatorna osnova Milana Lenucija,” 169-197. 


\section{REFERENCES}

Albers, Gerd. Entwicklungslinien im Städtebau. Ideen, Thesen, Aussagen 1875-1945. Texte und Interpretationen (chapter "Organisation der Planes"). Düsseldorf: Bertelsmann, 1975.

Albers, Gerd. Zur Entwicklung der Stadtplanung in Europa (chapter "Plantypen"). Braunschwig', Wiesbaden: Birkhäuser, 1997.

Cvitanović, Đurđica. "Arhitektura monumentalnog historicizma u urbanizmu Zagreba." Život umjetnosti 26/27 (1978): 127-160.

Dobronić, Lelja. Stari planovi Zagreba. Zagreb: Urbanistički zavod grada Zagreba, 1961

Dobronić, Lelja. Graditelji i izgradnja Zagreba u doba historijskih stilova. Zagreb: Društvo povjesničara umjetnosti SR Hrvatske, 1983.

Dobronić, Lelja. "Izgradnja Zagreba u devetnaestom stoljeću." Vijesti muzealaca i konzervatora Hrvatske 11 (1962): 144-159.

Faßbender, Eugen. Grundzüge der modernen Städtebaukunde. Wien, 1912.

Franković, Eugen. "Uloga Hermanna Bolléa u urbanističkom planiranju." Život umjetnosti 26/27 (1978): 40-57.

Franković, Eugen. "Regulatorna osnova Zagreba iz 1865. godine" Život umjetnosti 32 (1981): 48-59.

Franković, Eugen. "Gradnje, norme i spomenici." Arhitektura 36 (1983): 163-165

Franković, Eugen. "Regulatorna osnova istočnih područja Zagreba. Prilog poznavanju urbanizma na prijelazu stoljeća." Zbornik za narodni život i običaje Južnih Slavena 49 (1983), 245-274.

Franković, Eugen. "Lenucijeva era." Arhitektura 41 (1988): 81-111.

Geddes, Patrick. Cities in Evolution. London: Williams, 1915.

Gross, Mirjana. Počeci moderne Hrvatske. Neoapsolutizam u civilnoj Hrvatskoj i Slavoniji 1850-1860. Zagreb: Globus, 1985.

Gurlitt, Cornelius. Handbuch der Städtebaues. Berlin: Der Zirkel, 1920.

Hercher, Ludwig. Grossstadterweiterungen: Ein Beitrag zum Heutigen Städtebau. Göttingen, 1904.

Hoepfner, K. A. Grundbegriffe des Städtebaues. Second edition. Berlin: Julius Springer, 1921/1928.

Kadatz, Hans-Joachim. Beiträge zu mittel- und osteuropäischen Planungsideen des Städtebaues. Berlin, 1995.

Knežević, Snješka. Zagrebačka Zelena potkova. Zagreb: Školska knjigia, 1996.

Knežević, Snješka. "Regulatorna osnova Milana Lenucija za dio Zagreba od željezničke pruge do rijeke Save iz godine 1907." Radovi Instituta za povijest umjetnosti 16 (1992): 169-197

Knežević, Snješka. Zagrebu u središtu. Chapter "Željeznička pruga - omča Zagreba." 155-183. Zagreb: Barbat, 2003.

Knežević, Snješka. "Lenuci i 'Lenucijeva potkova'." Radovi Instituta za povijest umjetnosti 18 (1994): 169-189.

Knežević, Snješka. "Zagrebačke planirane vojarne iz doba Habsburške monarhije." In Zbornik II. kongresa hrvatskih povjesničara umjetnosti. Zagreb: Institut za povijest umjetnosti, 2007.

Ladd, Brian. Urban Planning and Civic Order in Germany, 1860-1914. Cambridge: Harvard university press, 1990.

Lavedan, Pierre. I.Qu'est-ce que l'urbanisme, introduction à I'histoire de l'urbanisme. Paris: Laurens, 1926.

Maruševski, Olga. "Grad za pedeset tisuća stanovnika." Kaj 1 (1983): 49-63.

Maruševski, Olga. Iso Kršnjavi kao graditelj. Zagreb: Društvo povjesničara umjetnosti SR Hrvatske, 1986.
Milanja, Cvjetko. Konstrukcije kulture. Modeli kulturne modernizacije u Hrvatskoj 19. stoljeća. Zagreb: Institut društvenih znanosti Ivo Pilar, 2012.

Morandi, Corinna. "Italian Planning in the later 19th century. The Milan example." Planning Perspectives 7 (1992): 361390. https://doi.org/10.1080/02665439208725756

Pedrini, Antonio. La città moderna. Milano, 1905.

Schumacher, Fritz. Vom Städtebau zur Landesplanung (und) Fragen städtebaulicher Gestaltung. Tübingen: Ernst Wasmuth 1951.

Stübben, Josef. Der Städtebau. Darmstadt, 1890.

Unwin, Raymond. Grundlagan des Städtebaues. Berlin, 1910.

"Vorträge und Aufsätze zur Städteaustellung." In Jahrbuch der Gehe-Stiftung, Die Großstadt. Dresden, 1903. 


\section{SUMMARY}

\section{Urban Planning of Zagreb in the Age of Modernization}

The process of modernization of Zagreb began much later than in other crown lands of the Habsburg Monarchy, only with the fall of Neoabsolutism (1859), and reached its peak during the office of Ban Ivan Mažuranić (1873 - 1880) and important reforms he decreed. During the period of modernization, formative for urban physiognomy of Zagreb, two general urban plans were adopted, in 1865 and 1887 respectively, and at the end of the period, in 1907, the chief urban planner Milan Lenuci proposed a sketch of a new general plan that never came to be realized.

The first regulatory plan of Zagreb was presented and approved in 1865. Its elaboration included two main sections: trade and political on one hand, and technical on the other. The accompanying text contains indirect criticism of Austrian political and administrative system, marked by considerable delay in comparison to the rest of Europe as well as by reluctance in introducing modernization reforms. The 1865 regulatory plan provided a spatial and functional definition of the lower part of the city and the basis for the creation of Donji grad (Lower Town), the key element of Zagreb's urban, architectural and cultural identity. New ideas and urgent requirements provoked discussions on particular features of the first plan, encouraged ideas on its revision and ultimately led to the development of a new regulatory plan. Crucial in this process were the decisions on framing the centre of the Lower Town with garden squares (the so-called Zelena potkova - Green Horseshoe) and on the new location of the military barracks complex on the eastern outskirts of the city.

The general (regulatory) plan presented in 1887 covered a much larger area than the first one and included the new feature of zoning of the city territory into three "sections" (zones), marked by different functions and different levels of elaboration. Requests for revision of this plan appeared as early as 1895 and were prompted by the Budapest urban railway line (Nagykanizsa - Zákany - Zagreb) constructed in 1868, which became an obstacle in traffic communication with the southern railway areas. That obstacle became even greater with the construction of Zagreb central train station (opened in 1892) and the mechanical workshop (largely in operation from 1894). In 1907, Lenuci submitted a proposal for a general regulatory plan for the entire metropolitan area titled "Basis for the future layout of railway regulations". He proposed a radical solution of removing the rail tracks from the urban area, which provided the basis for connecting urbanized parts of the city, especially the Lower Town, with the new "southern" Zagreb, to the Sava River. This plan was never given the status of a legal document, because Lenuci's solution of the so-called railway node was contested by higher government authorities for political and financial reasons. However, in terms of extent, zoning and structure, and most of all due to its visionary character, Lenuci's sketch, as he called it, represents the high point of urban planning in Zagreb - on the eve of modernism.

Dr. sc. SNJEŠKA KNEŽEVIĆ (1938.), povjesničarka umjetnosti, novinarka, književna prevoditeljica. Objavila je pet knjiga posvećenih urbanističko-arhitektonskim i kulturno-povijesnim temama Zagreba: Zrinjevac - 1873 - 1973. (1994.), Zagrebačka Zelena potkova (1996.), Zagrebu u središtu (2003.), Zagreb: grad, memorija, art (2011.) i Zagreb u škarama (2018.); stotinjak znanstvenih i stručnih radova, uredila više stručnih knjiga i zbornika te tridesetak elaborata ekspertiza na području zaštite kulturnih dobara.
SNJEŠKA KNEŽEVIĆ, PhD (1938), art historian, journalist, literary translator. Author of five books dedicated to themes in urbanism, architecture and cultural history of Zagreb: Zrinjevac - 1873 - 1973. (1994), Zagrebačka Zelena potkova (1996), Zagrebu u središtu (2003), Zagreb: grad, memorija, art (2011) and Zagreb u škarama (2018), around hundred scholarly and professional papers and around thirty expert reports related to cultural heritage protection; she has also edited several books and conference proceedings. 